Research Paper

\title{
Options for Post-Election Conflict Resolution in Africa
}

\section{Pedzisai Sixpence $^{1}$, Alouis Chilunjika ${ }^{1}$, Emmanuel Sakarombe $^{1}$}

${ }^{1}$ Department of Politics and Public Management, Midlands State University, 100 Buchwa Road Zvishavane. Zimbabwe.

Article History

Received:

27.12.2020

Revised:

23.01.2021

Accepted:

23.02.2021

*Corresponding Author:

Pedzisai Sixpence

Email:

spedzisai2012@gmail.com

This is an open access article, licensed under: $C C-B Y-S A$

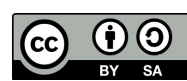

Abstract: Elections in most emerging democracies are generally characterised by irregularities which in turn fuel violent and non-violent expressions of displeasure before, during and after the voting excise. This paper discusses options for post-election conflict resolution with focus on African experiences since 2000. The paper holds that political and nonpolitical, local and international actors, play a dire role in ensuring that election-related insecurities are at least pacified. The paper assessed the constitutional, political and diplomatic alternatives to post- election conflict resolution. The paper goes further to examine the challenges that faced by African states in their exertion to deal with post-election conflicts. The study provides recommendations to inform the successes of the he post-election conflict resolutions in Africa. This paper establishes that most African states have lucrative legal frameworks on conducting elections and dealing with post-election unfortunate eventualities, the most compromise comes from, however, lack of political will and respect for the municipal ad international regulations. Furthermore, the paper realises that the continent, in some cases, lacks capacity and effectiveness on policy implementation to enforce electoral outcome or court rulings.

Keywords: Conflict Resolution, Post-Election, Violence. 


\section{Introduction}

The holding of intervallic legislative and presidential elections have become a regular practice world over with Africa not being an exceptional case. Since the beginning of the 21 st century, the African continent hosted more than 2000 electoral sessions with 2020 alone expected to have 12 electoral sessions [1]. While that is viewed as an achievement towards the realisation of utopian democratic societies, there is a worrying trend of post-election conflicts on the continent. For instance, Madzimre \& Machivenyika [2] noted that of the more than 100 elections held in 44 Africa states between 2011 and 2017, violence was recorded in all the electoral sessions though in varying magnitudes. The intensity of violence in these cases are so worrying considering the high mortality rates that were recorded. During the 2005 Ethiopian elections, more than 2000 people died; In the 2007-8 election in Kenya more than 1500 and 6000 deaths and Internally Displaced Persons (IDPs) respectively were recorded; in 2010, more than 3000 people died in Ivory Coast [3] [4]. There has been a mounting literature on the causes, the key players and effects of election related ferocity in Africa. There is, however, no comprehensive research link between these experiences and sustainable post-election conflict resolution options in African. This study examined literature, conference presentations, international and local legal statutes and other open sources to scrutinize the practices of African countries in view of post-election conflict resolution in the past two decades. This exploration, therefore, pursues the main causes of election related rows on the continent which ranges from preelection violence to accusation on lack of level electoral field [5] [6] to electoral fraud in understanding the post conflict resolution alternatives for Africa. Having noted that, this study deliberates on the use of constitutional mechanisms, investigations, negotiations and military interventions as venues to the end in post-election conflict resolution which include the upholding of electoral outcome, power sharing and amendment of the electoral laws.

\section{Post-Election Conflict Resolution}

Post-election conflict refers to any election related violent and or nonviolent expression of dissatisfaction to part or whole of the electoral process by some or all of the parties to an election [7]. From that, post-election conflict resolution, therefore, refers to any initiative by the government, political parties, regional or international actors to, at least, ease the tensions among the parties to the conflict and, at most, come up with solutions for a sustainable progressive outcome. In this section, the study debates the main processes and outcomes of such process in post-election conflict resolution.

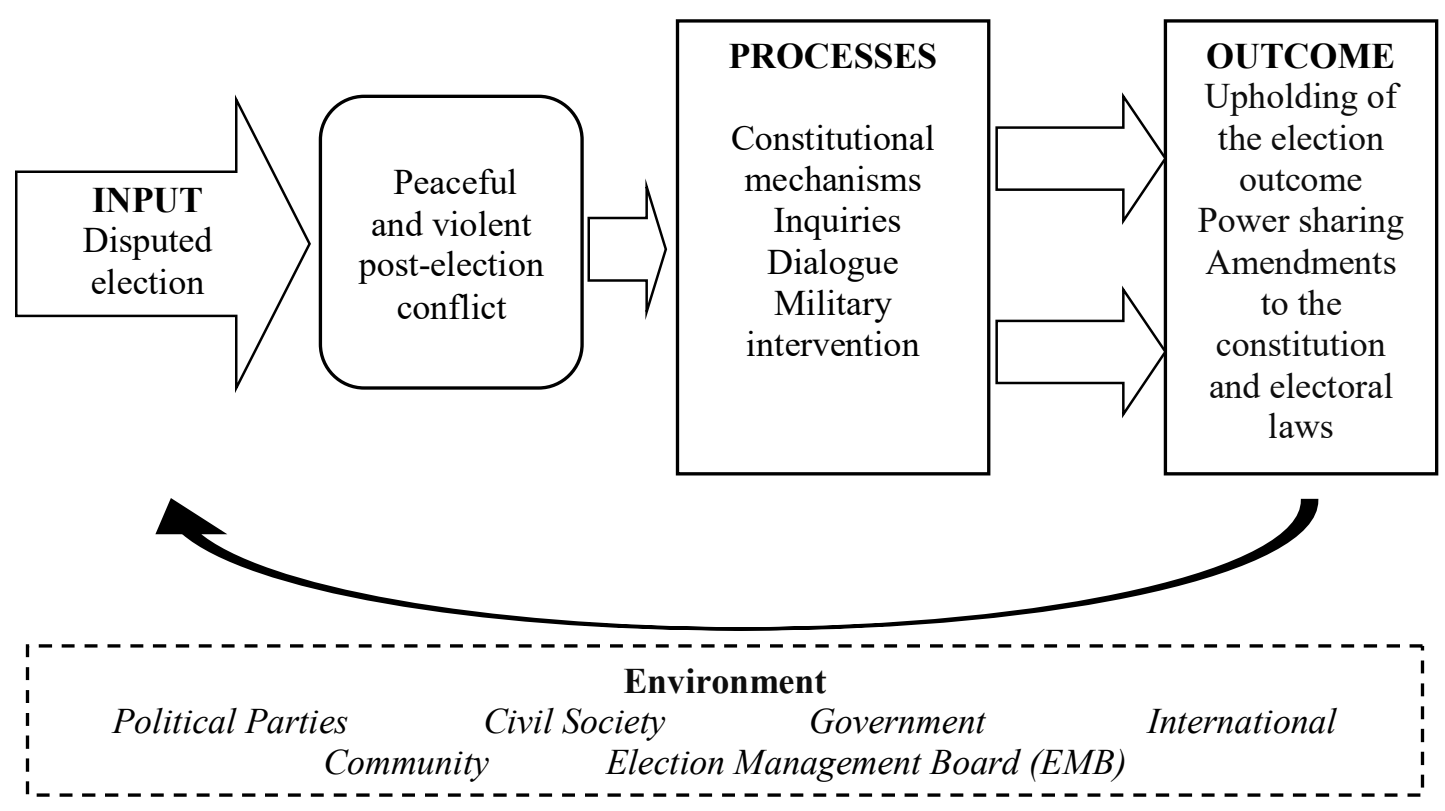

Figure 1. Post-Election Conflict Resolution as a Process 
Figure 1 outlines in general the processes of post-election conflicts. It shows the causes of such conflicts, the available resolution processes and their outcomes. Additionally, fig 1 insinuates that the success of the conflict resolution efforts in post-election situations depend on the state of an array of environmental factors from the local and international spheres.

\subsection{Constitutional Mechanisms}

Participants to an election can only acknowledge the legitimacy of the election results if the electoral process adhered to the guidelines of the electoral laws. In an opposite scenario, the aggrieved can use the local procedures to test the outcome with the guidance of the electoral law. In recent years, the option was used in a number of African countries [2] [8]. For instance, in the main contestant in Kenya's presidential elections in 2017, Raila Odinga, challenged the presidential election results in the Supreme Court. The court annulled the presidential election results highlighting that the tabulation process had not been done in a manner that satisfies the constitutional requirements. In 2018, the presidential candidate of the main opposition, Nelson Chamisa, challenged the outcome of the presidential election in the country's supreme court, the supreme court, however, upheld the election result citing in availability of evidence to substantiate the allegations raised by the applicant. In February 2020, the constitutional court of Malawi overturned results of the May 2019 presidential elections ordering among other things, the review of the country's electoral law and the holding of a fresh presidential election. In the same month, the Supreme Court of Namibia dismissed a bid by the country's opposition to have the presidential election nullified.

While the outcome of an electoral court cannot be predicted, it is paramount to note that the losers of court rulings in all these incidents have displayed a related tendency of accusing the judiciary for being incomplete. In that regard, it becomes crucial to note that courts can only professionally handle post-election cases if they are competent, honest, learned and independent [9]. Moreover, constitutional mechanisms work effectively with the support of the law enforcement mechanisms. This way, there is need for the law enforcement agencies to be ready to enforce the court outcome in an apolitical way. In cases of further resistance, the regional and international community can invoke peaceful means of settling the dispute by making use of Chapter VI of the UN Charter which consist of mainly diplomatic, political and economic means.

\subsection{Inquiry}

Investigative Commissions as noted by Herik [10] are "mandated to investigate human rights violations specifically to identify responsible perpetrators of crimes and suggests recommendations." A Commission of Inquiry can have its mandate varied depending on prevailing circumstances under which it has been established [11]. In post-election conflict, the use of fact-finding commissions is essential to explore allegations of violations at any stage of the electoral process at national or regional level or over a long period of time or on a specific incident. The use of Commissions of Inquiry as an apparatus of conflict resolution is derived from the 1899 Hague Convention from an International Law (IL) perspective and, in municipal situations, from the provisions of domestic constitutions. In case of the former, investigative commissions can be established by the United Nations (UN) and Unites Nations Security Council (UNSC); the United Nations General Assembly (UNGA) and other UN specialised agencies [11]. In the context of the AU, the African Union Peace and Security Council (AUPSC) is charged with the responsibility of establishing Commissions of Inquiry to investigate on cases of violence on the continent. In the case of Zimbabwe's post 2018 election conflict, the President of the Republic, Emmerson Mnangagwa, appointed a Commission of Inquiry as provided for within the country's legislations specifically section 2(1) of the Commissions of Inquiry Act [Chapter 10:07] through Proclamation Number 6 of 2018 published in Statutory Instrument 181 of 2018. The Commission, generally known as the Monthlante Commission, was tasked to study the post-election conflict in the country. The 1 August 2018 violence resulted in death of six (6) and injure of around 35 civilians as well as destruction of property in the Harare's Central Business District (CBD)

\subsection{Dialogue}

A political dialogue is one of the inclusive peace processes whereby parties to political conflict make effort to secure solutions to problems facing a country [12]. In post-election conflicts, a political dialogue can be useful in easing relations between and among parties to a just ended election. To this 
end, Nilsson [13], contends that political dialogue provides concerned actors with an opportunity to generate lasting solutions and establish a combined and coordinated plan of redesigning the political, social and economic trajectory for the country. Political dialogue as a post-election conflict resolution process may result in power sharing. A typical example are the experience of Kenya and Zimbabwean 2008. In February 2008, then then President of Kenya, Mwai Kibaki, representing the ruling party, the Party of National Unity (PNU) signed the National Accord and Reconciliation Act which formed the basis for a Government of National Unity (GNU) between his party and the main opposition, ODM, led by Raila Odinga. In the same year, the then President of Zimbabwe, Robert Mugabe and the leader of the main opposition party, the Movement for Democratic Change (MDC), Morgan Tsvangirai signed the Global Political Agreement (GPA) allowing for the formation of a GNU. As such, the focus of a dialogue aims at clearing contestations over an election and allow the formation of a progressive government, acknowledged by, at least, most of the parties to the election. This allows for taking the nation off the election temper and allow for a broadminded political environment. Successful dialogue should be inclusive, tolerant, and transparent and have measurable and realistic implementation framework [14].

\subsection{Military Intervention}

Military intervention as a conflict resolution strategy is provided for in the Chapter VII of the UN Charter. Article 42 of the UN Charter provides that, the Security Council may take such action by air, sea, or land forces as may be necessary to maintain or restore international peace and security While the Charter does not authorise regional organisations to intervene militarily in situations that require such action, the dynamics in international peace and security towards the end of the 20th century obliged regional organisations to change their legal regimes with regards to conflict resolution strategy.

Accordingly, the African Union (AU) came up with a revised act to match the evolving requirements. For the $\mathrm{AU}$,

Article 4(h) and (i) of the AU revised: (h) The right of the Union to intervene in a member state pursuant to a decision of the assembly in respect of grave circumstances, namely: war crimes, genocide and crimes against humanity; and (j) the right of member states to request intervention from the Union in order to restore peace and security.

To add, the African Union Peace and Security Council (AUPSC) Protocol also reinforces the same point.

Pursuant to the foregoing, RECs such as the ECOWAS through Article 4 of the ECOWAS' revised treaty [3] and SADC through Article 11 (2-4) of the OPPDSC also aligned their regional protocols to allow for military interventions in cases similar to those prescribed by the AU and the UN Charters. Through these legal developments, RECS are authorised to intervene for such action in cases of violations of practice of good governance, but only, in consultation with UNSC as provided for in Chapter VIII Article 53 of the UN Charter.

With regards to military interventions as a post-election conflict resolution option in Africa, the ECOWAS interventions or threat of it, is edifying on the effectiveness of this option. Following the disputed election of December 2016 in which the incumbent, President Yahya Jammeh, refused to hand over power to the declared winner, Adama Barrow, ECOWAS instituted the ECOWAS Military Intervention in The Gambia (ECOMIG) to intervene in the country (Hartmann 2017). Although the UN, through the UNSC Resolution 2337 did not specifically authorise ECOMIG operation, yahya Jammeh only agreed to step down when ECOMIG forces had surrounded The Gambia, charging towards its capital [3].

\subsection{Power Sharing}

Power sharing in post-election conflict resolution is a political arrangement between and among contesting political parties in a country to which a unity government or a transitional authority is formed. Cheeseman [15] defines power sharing as, "the creation of an inclusive government in which cabinet posts, and hence executive power, is shared by the major parties in a given conflict. In Africa, the choice of power sharing as a post-election conflict resolution strategy was influenced by the perceived or actual successes credited to the same strategy in conflict resolutions in cases such as Rwanda, Uganda, DRC, and Angola. The rationality of power sharing in post-election conflict 
resolution, as argued by Cammett and Malesky [16], is that parties incorporated in a power sharing arrangement will likely have combined interest in the stability and functioning of that political arrangement. Deliberations for power sharing are usually done through a political dialogue. Accordingly, it can be reasoned that power sharing is ideal to solve post-election conflicts emerging after an acute debacle over the trustworthiness of an election. Power sharing is, however, given a stipulated time frame depending on the circumstances leading to its formation. In some cases its lifespan can be determined by the time spent to achieve a set of targets which the transitional government is mandated to execute. In most cases, transitional governments are established to allow for the drafting and enactment of a new constitution or electoral laws. The Government of National Unity (GNU) in Zimbabwe was established in 2009 and ended with an election in 2013 after writing a new constitution and enacting a number of electoral law reforms. In the case of Libya, the Government of National Accord (GNA) established in 2015 with the inspiration of the UN is still in place, though with limited control over the eastern parts of the country. The country is facing challenges to hold an election and the transitional government has since overstayed its estimated lifespan.

\subsection{Electoral Reforms}

Electoral reforms refer to political, administrative and legal adjustments to an electoral system [17]. Electoral systems, refers to, "... set of rules for conducting an election and the legal and administrative framework and procedures adopted for translating votes into seats." Electoral reforms should, as argued by Toros and Birch [6], "allow voters to be able to express their genuine electoral preferences safe from outside influence." Electoral reforms centre on the whole or part of the components of the electoral cycle. On the African continent, electoral reforms came as a result of the evolution of multiparty democracy as a way of resolving election related conflicts. The IDEA [17] thus, indicates that several African countries have, "made changes to voter registration rules and electoral system design, introduced gender quotas and other affirmative action measures to enhance the participation of different and multiple players..." Electoral amendments are, therefore common on the African continent. Briefly, electoral amendments do not intend to mend election results of previous elections and should be conducted by an independent and impartial panel (Omotola 2020). Key examples of this arrangements includes Comoros (2018); DRC (2016); Kenya (2010); Madagascar (2010) and Zimbabwe (2013) among other [18].

\section{Impediments to Post-Election Conflict Resolution in Africa}

Post-election conflict resolution in Africa is marred with an array of complications making it a troubled peace process. According to Daniel and Enweremadu [19], these challenges are among others, political and financial. There has been a visible decline in quantities and intensity in such conflicts pointing to the usefulness of the available conflict resolution options. Questions, however, remain on whether the conflict resolution basket available for Africa can offer lasting solutions to the problems on the continent or are just convenient for freezing conflicts [20].

Provision for negotiated power, in Africa and elsewhere, risks promoting political actors to abuse their access to hard and soft power and push for an agenda beyond the electoral process into power sharing. The tendency of those in power to permanently cling to it sometimes shows that there is always an existing possibility of those in power to resist election results that adversely affect them if the democratic culture is ailing. Typical examples include Kenya (2007); Zimbabwe (2008); Cote d'Ivore (2010); and the Gambia (2017). In this case democracy is victimized by the "worst case scenario choice." The worst case scenario choice exist when all parties to a conflict are not willing to compromise and reason for an alternative solution that comes before exhaustion of the options available even if they are aware of their wrongful act. In case of post-election conflict resolution, parties would rather push for instability until the option of power sharing is considered. This has resulted in the creation of Transitional Authorities (TA) or Governments of National Unity (GNU) in several African states as it become difficult to conclude elections with parties agreeing on the outcome. This was the case in Kenya 2008; Zimbabwe 2009; and Madagascar 2010. Learning from such experiences, this study hold that the future of post-election conflict resolution in Africa is not as bright as anticipated as political players are likely to continue in that trajectory. Indications are that, countries such as Kenya and Zimbabwe are likely to linger on the same course through to the upcoming 2022 and 2023 elections respectively. 
Correspondingly, the sustainability of these constitutional and political post-election conflict resolution approaches in Africa are disturbing. It can be contended that diplomatic and political postelection conflict resolution mechanisms, if anything, shelve or freeze conflicts [20]. Frozen conflicts, according to Mosashvili [21], "impede economic and human development, shape the daily lives of millions of people and confront the international community with serious challenges." This is so because the parties in the negotiated deal usually enters into a power sharing deal with short term objectives and in most cases, the term is so specific as marked by the life span of the power sharing or the transitional governments emerging from such arrangements. As such, elections become rituals to create an environment for the renewal of the similar pact. Experiences in most African states that have had TAs or GNUs shows that the preceding elections usually result in post-election conflicts and parties need to continuously hold a dialogue which in some cases may not be successful. For instance Kenya after the expiry of the GNU experienced post-election violence in 2013 and 2017; Zimbabwe after the GNU f 2009-13 witnessed post-election violence in 2018.

Another visible challenge is that of political spillover effect. While this is not always the case in political development as Babych [22] opines that political initiatives in one country may at times spillover to other countries. Events leading to the fight and attainment of independence by African states in the last half of the 20th century and the collapse of the Soviet Union (SU) in the 1990s are all evidence to the international spillover effects on peace and security [21]. The ripple effects that negotiated peace deals have had over the continent is visible in compound incidents. The Arab Spring revolutions that started in Tunisia in 2011 easily spread and disturbed the Middle East and North Africa (MENA) region and remain the source of major ongoing conflicts in Libya, Syria, Sudan and Yemen. In Southern Africa, there has been a visible cooperation and influence between and among opposition political parties. Visible examples are Alliance for Change and Transparency (ACT) of Tanzania, Democratic Alliance (DA) South Africa; Movement for Democratic Change (MDC) Zimbabwe; Orange Democratic Party (ODP) Kenya; United Party for National Development (UPND) ZambiaFor instance, the successful negotiated political power arrangement in Kenya in 2007, is argued to have influenced the developments in Zimbabwe as the same template was adopted leading to a GNU coming into effect the following year. Extension of presidential term limits have also been occurring in a similar pattern [23]. Constitutional amendment to allow for the extension of presidential term limits was easily exported from Rwanda when in 2015 the country held a referendum whose results allowed President Paul Kagame to run for a 3rd term (7 years) from 2017 and an extra 2 five-year terms thereafter; to Uganda where in 2017, a constitutional amendment eliminated the presidential age ceiling of 75 Years only allow President Yoweri Museveni to participate in the upcoming 2021 elections; and Burundi where the 2018 constitutional amendment allowed President Pierre Nkurunziza to run for an extra 2 terms. The same amendment also increased presidential term tenure from 5 to 7 years. In 2017 the Kenyan's main opposition, the Orange Democratic Movement (ODM), as well as Zimbabwe's main opposition coalition, the Movement for Democratic Change Alliance (MDC-A) in 2018, challenged presidential vote but accepting their defeat in the parliamentary elections. Captivatingly, in the succeeding year, elections in Malawi, Botswana and Namibia were all challenged in the courts. The frequency of electoral challenges in Africa brings suspicion on whether these are not influenced by the realisation that constitutional channels is the route to negotiate political power sharing and ultimately GNU? With the case of Malawi having led to the nullification of the presidential election, it can be projected that similar challenges on election results are going to be more in the upcoming elections.

This study also advances that Africa risks realising a growing political polarity if post-election conflicts are not dealt with decisively and sustainably. Polarised communities are vulnerable to violence throughout the election processes. Negotiated political power as a post-election conflict resolution, can partly be blamed for the hardline stance, the "us versus them" political standing, the failure to separate real issues from trivial issues, among the conflicts effect disturbing Africa. This can be contributing to some continued violence on the continent. The parties to the conflict continue to escalate violence through hate speech, to heighten their relevance in the political developments of their respective countries. This is meant to yield bargaining influence on the presumed negotiating table. In that way, most African countries with evidence of political polarisation remain in the election mood, with election legitimacy taking the centre of every discussion years after the election.

Furthermore, the setup of negotiated political power in Africa violates, in most cases, the democratic principles by excommunicating smaller political outfits in the post-election conflict 
resolution imaginations. In most if not all cases, only the most influential political parties are given space in post-election conflict resolution and subsequently emerge winners. For instance Horowitz [24] intimated that in 2008, the ODM and the PNU of Kenya dominated the process and benefited from the resultant transitional government sharing among them the influential posts in that creation. In Zimbabwe, the 2009 GNU mostly accommodated the MDC and the ZANU PF formations regardless of the fact that more political parties participated in the disputed election. Besides, the same development renders election a useless practice as the powerful will continue to violate them. Politically negotiated power sharing arrangements make the other post-election conflict resolution mechanisms means to an end and not the end in themselves. As such, there has always been the use of the inquiries, negotiations, political dialogue, electoral law amendments and constitutional changes as means to justify the need for a power sharing arrangement by the bigger actors.

Additionally, post-election conflict resolution in Africa is affected by the prevalence of dynastic politics. Dynastic politics exist when one or a few families dominate the influential postures in the government and the security sector of country. The challenge becomes more visible when it comes to succession in Africa. Helms [25] argues that, "the politics of leadership succession is of crucial importance to the development of political regimes more generally." While this is evident even in democracies beyond Africa, the cases are so high in Africa making it difficult to expect a meaningful conflict resolution in post-election crisis. For instance, majority of the elite politicians do strategically appoint their close family members to head the Police, the Army and the Intelligence units while in some cases to even succeed them. Examples include the Khama family of Botswana; the Kabila family of the DRC; Ondimba family in Gabon; the Addo family of Ghana; the Kenyatta of Kenya; Ramgoolam of Mauritius and Gnassingbe of Togo. With this setup, it remains imaginary in some of these situations to expect sustainable post-election conflict resolution even in the presence of lucrative legal frameworks as politics become the central factor.

Post-election conflicts in Africa are also vulnerable to the vagaries of politicised ethnicity. Ethnical complexities of most of African countries provide sumptuous ground for possible post-election conflict [18]. In such cases, it is difficult to have an approved elections as politicised ethnic formations are propped up to take the election as an opportunity to advance their ethnic induced political goals. The cases of the Kikuyu, Luo and the Kalenjin political affiliations in Kenya, the Arabic Muslim and the Christian blacks in Sudan before the 2011 secession of South Sudan, experiences of Comoros, Madagascar and many other African states all point to that possibility. In these cases, politicians deliberately politicise ethnical lines to push for their agenda ignoring the results of legitimate election, thus, making the election in a multiethnic society less meaningful.

The prevalence of armed conflicts on the continent are also a stumbling block towards the realisation of lasting post-election conflict resolutions. The DRC, Mozambique, South Sudan, Sudan, Somalia, Libya, Nigeria, Mali are all experiencing terrorist or armed conflicts in all or certain parts of their territories. In consequence, it is difficult to conduct elections in such areas as the rebel dominated eastern parts of the DRC, the terrorist run Cabo Delgado province of Mozambique, most parts of Somalia including the capital Mogadishu, the eternity of Libya, the Boko Haram dominated Sambisa area of Nigeria and the Twareg rebels affected areas in Mali. Furthermore, it is worrying to realise that, even if authorities push for the conduct of elections in these areas, like is sometimes happening, it is difficult to opt for constitutional post-election conflict resolution. The elections in themselves, become a new source of conflict to add on the already existing issues.

While the UN, AU and sub-regional agreements provide for the role of the same in post-election conflict resolution, there are some worrying institutional challenges to these organisations. The AU and its sub-regional organisations have inherent challenges chief among them, financial and military. As such, conflict resolution mechanisms of these institutions become problematic. It can be noted that since 2002, when the inaugural AU Head of States summit was held in South Africa, the need for a Common African Defense (CAD) was made clear. It is worrying, however that, 18 years down the line, the AU is still battling with the hurdles to establish the proposed Africa Standby Force (ASF). The establishment of regional military responses in the name of the African Capacity for Immediate Response to Crisis (ACIRC) in April 2013 created longer challenges than expected. ACIRIC was meant to be a stop gap measure to provide the continent with the deployment capability as the Regional Economic Communities (RECs) readied for their components of ASF ahead of the 2015 deadline. The continent, however continue to deliberate on how this can be operationalised as there seem to be compromised will by some member states who enjoy influence on regional than 
continental military establishment. Finance remain at the centre of the challenges as well. In the case of the challenges faced by the ECOWAS in Cote d'Ivore in 2011, Daniel and Enweremadu [19], noted that, "the lack of a standing force by ECOWAS was seen as a limitation to a military intervention in the post-election crisis in Cote d'Ivoire."

\section{Conclusion}

In summary, this analysis examined the main postelection conflict resolution facilities commonly used globally but with specific reference to the experiences of Africa. The paper indicates that although there are lucrative options with regards to conflict resolution in most election environments, there is need for enhanced political will as a key ingredient towards the success of these mechanisms. He research further proposes that governments continue to be tolerant on issues of plurality so that there will not be issues of exclusion, a nucleus force behind majority of post-election political and security explosion. Having identified and discussed the main challenges compromising the efficacy of postelection conflict resolution in Africa, this paper also proposes recommendations that African states, regional organisations and non-governmental organisations can consider in fortifying, perfecting and supporting the existing post-election conflict resolution mechanisms.

This study acknowledges that the discussed options for post-election conflict resolution in Africa allow the parties to the conflict to have more time to reflect on their long term goals, appreciate the other party, and acknowledge their join relevance in nation building. This way, the paper recommends that political and nonpolitical players on the African continent consider the options to halt any possibilities of post-election political explosions. For instance, Horowitz [24] indicates that power sharing in Kenya allowed for the conflicting parties in the country to have more time to address the root causes of the conflict as provided for by Agenda Four of 2008. This way, these conflict resolution mechanisms provide an opportunity for the key players in the government to address key causes of election related violence. This may include drafting a new constitution and the reform of electoral laws. Kenya new constitution of 2010 and Zimbabwe new constitution of 2013 followed successful political dialogue and power sharing arrangements as post-election conflict resolution efforts.

Additionally, the analysis sees an opportunity in supporting governments and political players to exhaust provisions of their internal constitutional remedies to post election conflict resolution. If proven that elections where not free and fair, this paper recommends the use of court appeals as provided for in almost all electoral laws throughout the continent. The study appreciates the role of the local courts as evidenced in the discussed cases. The paper, however, challenges authorities to respect the constitution and judicial decisions as well to ensure restoration of peace beyond postelectoral misunderstandings. Although court rulings may find political resistance, their legitimacy is, somehow, better than that of a negotiated political power sharing and are less devastating as compared to military interventions. Learning from the selected cases such as Botswana (2019; Kenya (2017); Malawi (2019); Namibia (2019; and Zimbabwe (2018), this paper opines that the failure by one party to prove before the courts, of its allegation, should be enforced by the law enforcement agencies with its firmness.

This challenges African governments to, if they are confident with their electoral system, enforce electoral outcome or court rulings in such cases instead of folding their hands and allow lawlessness to prevail. Failure to do so can be disastrous as parties to the conflict may continue to cause schism and compromise national consistency. In the same way, the failure by the law enforcement agencies to enforce electoral or court outcome can be of a similar effect to cases of losing candidates resisting to leave office as ws the case in Cote d'Ivore and the Gambia. Although generally castigated, the law enforcement forces of every country should be equipped to subdue any form of anarchy in postelection, their constitutional guidelines on the use of force if need be.

Furthermore, this study appreciated demographic pluralism in most Africa states. Bearing that in mind, this study recommends that African leaders thrive for establishment of accommodative electoral systems to allow for proportional representations of the key elements in plural societies [18]. Failure to consider proportional representation fuels post-election conflicts as cleavages revolving around issues such as ethnicity and religious differences can lead to conflicts. Daxecker [26] insinuates that, "institutional biases emerging from malapportionment affect motivations and opportunities for postelection violence." In this regard, this study reasoned that electoral systems should ensure proportional representation. This can be done as a substitute of or means to integration. 
This include the establishment of the position of leaders of opposition in parliament and proportional allocation of cabinet posts to political parties depending on their parliamentary performance in the election. Regardless of the various challenges associated with it, this research suggest that power sharing can be prescribed for such societies where there is no hope for integration. For instance, Cheesman [15] states that, "power sharing and group autonomy are meant generally to ensure representation for all politically relevant groups and foster an overall sense of inclusion." In some cases, countries like Madagascar, Mauritius, and Seychelles, in their constitutions deliberately accommodated the diverging groups in their respective countries as a way of minimising possibilities of conflict [18].

Pursuant to the foregoing, this paper recommends that governments should cooperate with regional, international and non-governmental organisations in enhancing their electoral systems as well as handling post-election conflict resolution. On the establishment of electoral legal framework, the AU's African Charter on Democracy, Elections and Governance and its RECS provides guidelines on how to hold credible elections in the continent, the role of organisations such as the European Union (EU), Through the Joint Africa-EU strategic partnership, EU fund the AU to enhance AUEOM operations. The European Centre for Electoral Support (ECES) which has been Instrumental for funding and capacity building of organisations in Africa including AU, ECOWAS, ADC and other local organisation, the International Foundation for Electoral Systems (IFES) which was Instrumental in the establishment of Kenya's Independent Electoral and Boundaries Commission (IEBC) in 2011 and the Election Support Network-Southern Africa (ESN-SA) known for working with non-partisan electoral support networks in Southern Africa are among such organisations. Furthermore, Rao's [27] analysis acknowledges the role of international and regional organisations in enforcing electoral outcome in case of resistance. In 2017 the UN, AU and ECOWAS jointly pressurised the incumbent, President Yahya Jammeh to vacate office after electoral loss. Beyond, capacity building and funding, this study further recommends that governments invite credible observer missions to allow for a wider opinion which counts on credibility of an election. Major EOMs in operating in Africa include: UNEOM, the EUEOM, AUEOM, SADC-EOM, ECOWAS-EOM, EAC-EOM, and the Office for Democratic Institutions for Human Rights (ODIHR). Through regional and international organisations, this study opines that African states can also consider assistance in form of military backup in the event an enervation of political and diplomatic options without material yield.

This analysis advances the idea that a credible election should be run by an impartial board set up in accordance to the provisions of the electoral law of the country in question. According to AlMusbeh [7] an Elections Management Board (EMB) is any authority responsible for administering elections in a given country. This study prescribes that countries ensure that their EMBs are impartial, dependable and capable to run a credible election. This study also recommends that authorities do everything to their ability to invest in building public confidence in the legal and operational framework of the EMB. The research notes that while in many countries EMBs are rhetorically independent, there is a lot of political interference especially by the incumbent political players. From that, it is recommended that members of EMBs be selected on the basis of merit but not withstanding the aspect of political representation. The capabilities of an EMB is influenced mainly by the level of resources it has access to, both material and human resources. To achieve this, this paper hails the cooperation between EMBs and regional and international organisations to realise this. IFES was instrumental in the format of the IEBC of Kenya in 2011; funding by Zimbabwe United Nations Development Assistance Framework (ZANADAF) to the ZEC's 5 year (2016-2020)capacity building project (ZIM-ECO); Electoral Institute for Sustainable Democracy in Africa MoU with the AU on support to EMBs and electoral stakeholders

\section{References}

[1] J. Siegle, and C. Cook, Assessing Africa's 2020 Elections. Spotlight, 2020. [Online]. Available: https://africacenter.org/spotlight/highlights-africa-2020-elections/. [Accessed: April. 29, 2020].

[2] J. Madzimre, and F. Machivenyika, Just in: President Launches POLAD. The Herald, 2018. [Online]. Available: https://www.herald.co.zw/just-in-president-launches-polad/. [Accessed: September. 13, 2020].

[3] O. J. Adeagbo, and J. M. Iyi, "Post-Election Crisis in Kenya and Internally Displaced Persons: A Critical Appraisal," Journal of Politics and Law, vol. 4, no. 2, 2011. 
[4] HRW, "They Killed Them like It Was Nothing” The Need for Justice for Côte d'Ivoire's PostElection Crimes, 2011. [Online]. Available: https://www.hrw.org/sites/default/files/reports/ cdi1011WebUpload.pdf. [Accessed: September. 30, 2020]

[5] U. E. Daxecker, "The cost of exposing cheating: International election monitoring, fraud, and postelection violence in Africa," Journal of Peace Research, pp. 1-15, 2012.

[6] E. Toros and S. Birch, "Who are the Targets of Familial Electoral Coercion?," Evidence from Turkey, Democratisation, vol. 26, no. 8, pp. 1342-1361, 2019.

[7] M. Al-Musbeh, Managing Elections: Definition and Classification of Elections Management Bodies. 2011. [Online]. Available: file:///C:/Users/Blessing/Downloads/SSRN-id2271279libre.pdf. [Accessed: May. 04, 2020].

[8] K. K. Klomegah, "ECOWAS Recognises Guinea-Bissau's Presidential Election," Modern Diplomacy, 2020.

[9] O. Kaaba, "The challenges of adjudicating presidential election disputes in domestic courts in Africa," African Human Rights Law Journal, no. 15, pp. 329-354, 2015. [Online]. Available: https://www.researchgate.net/publication/328829899_The_Challenges_of_Adjudicating_Presid ential_Election_Disputes_in_Domestic_Courts_in_Africa. [Accessed: September. 1, 2020].

[10] L. Herik, "An Inquiry into the Role of Commissions of Inquiry in International Law: Navigating the Tensions between Fact-Finding and Application of International Law," Chinese Journal of International Law, vol. 13, no. 3, pp. 507-537, 2014.

[11] UN, Commissions of Inquiry and Fact-Finding Missions on International Human Rights and Humanitarian Law: Guidance and Practice, 2015. [Online]. Available: https://www.ohchr.org/ Documents/Publications/CoI_Guidance_and_Practice.pdf. [Accessed: March. 29, 2020].

[12] I. Mendes, "Inclusion and Political Representation in Peace Negotiations: The Case of the Colombian Victims' Delegations," Journal of Politics in Latin America, vol. 1, no. 26, 2020.

[13] M. Nilsson, "Civil society actors in peace negotiations in Central America," Journal of Civil Society, pp. 1-18, 2018. [Online]. Available: https://doi.org/10.1080/17448689.2018.1484004. [Accessed: September. 03, 2020].

[14] T. Paffenholz, What Makes or Breaks National Dialogues? Inclusive Peace and Transition Initiative. Geneva, 2017.

[15] N. Cheeseman, the Internal Dynamics of Power-Sharing in Africa. Democratisation. Vol. 18, no. 2, pp. 336-365, 2011. [Online]. Available: https:/www.researchgate.net/publication/ 232951768_The internal_dynamics_of_power-sharing_in_Africa. [Accessed: April. 9, 2020].

[16] M. Cammett and E. Malesky, "Power Sharing in Post-conflict Societies: Implications for Peace and Governance," Journal of Conflict Resolution, vol. 56, no. 6, pp. 1-35, 2012. [Online]. Available: https://www.researchgate.net/deref/http\%3A\%2F\%2Fjcr.sagepub.com\%2Fcontent $\%$ 2Fearly\%2F2012\%2F07\%2F13\%2F0022002711421593. [Accessed: September. 13, 2020].

[17] C. Hartmann, "ECOWAS and the Restoration of Democracy in the Gambia," in. Africa Spectrum, vol. 52, no. 1, pp. 85-99, 2017.

[18] E. S. Poupko, an Exploratory Study of Constitutional Design in Three Island States: Seychelles, Comoros, and Mauritius. 2017. [Online]. Available: https://pdfs.semanticscholar. org/20a5/e0f88259c5ecd228bd0976b5b39c8bfc5d66.pdf. [Accessed: April. 17, 2020].

[19] D. A. Daniel and U. Enweremadu, "Potency of ECOWAS mission strategy in resolving electoral conflict in West Africa: A case of Côte d'Ivoire," African Journal of Political Science and International Relations. vol. 14, no. 1, pp. 22-32, 2020.

[20] M. A. C. Clancy, and J. Nagle, "Frozen Conflicts, Minority Self-Governance, Asymmetrical Autonomies In search of a framework for conflict management and conflict resolution," Paper to the 6th Asia-Europe Roundtable, Londonderry/Derry, vol. 10, no. 12, pp. 1-27, June 2009.

[21] G. Mosashvili, Frozen conflicts in Moldova and Georgia. Paper to the European Student Conference, 2019.

[22] Y. Babych, The International Spillover Effects of Political Transitions. Georgia: Tbilisi State University, 2017.

[23] M. Wiebusch and C. Murray, "Presidential Term Limits and the African Union," Journal of African Law, pp. 1-17, 2018.

[24] J. Horowitz, Kenya's Experience with Power-Sharing. Dartmouth College, 2013. [Online]. Available: https://cpb-us-e1.wpmucdn.com/sites.dartmouth.edu/dist/9/452/files/2016/08/Kenya -Power-Sharing-Oct-16-2013.pdf. [Accessed: September. 9, 2020]. 
Pedzisai Sixpence, Alouis Chilunjika, Emmanuel Sakarombe.

Options for Post-Election Conflict Resolution in Africa.

International Journal of Law and Public Policy, vol. 3, no. 1, pp. 49-59, March 2021. DOI: 10.36079/lamintang.ijlapp-0301.186

[25] L. Helms, "Leadership succession in politics: The democracy/autocracy divide revisited," The British Journal of Politics and International Relations, vol. 22, no. 2, pp. 328-346, 2020. [Online]. Available: https://doi.org/10.1177/1369148120908528. [Accessed: September. 9, 2020].

[26] U. Daxecker, "Unequal votes, unequal violence: Malapportionment and election violence in India," Journal of Peace Research, vol. 49, no. 4, pp. 503-516, 2019.

[27] P. Rao, "Gambia's democracy survives political turbulence: Peaceful transfer of power trending on the continent," Africa Renewal, May - July 2017. 